\title{
TWORZENIE BIBLIOTEK JAKO DZIAŁALNOŚĆ WSPIERAJĄCA WYCHOWANIE KU NIEPODLEGEEJ RZECZYPOSPOLITEJ
}

[Creating libraries as educational support activities aimed at the restoration of the independence of the Republic (Rzeczpospolita)]

Summary: In the eighteenth and nineteenth centuries collectibles and collecting spread within Europe, and bibliophilia was quite common. At the end of the eighteenth century, and following the plundering of the Republic by foreign invaders, citizens began to strive for independence and many patriots worked to save the achievements of Polish culture. They created collections that became the treasuries of Polish culture. The collections were aimed at saving valuable items before their dispersal or destruction, including Polish literature e.g. documents, letters, diaries, and any records of scientific achievements. The collections also gave rise to numerous initiatives aimed at educating the Polish nation and fighting against national destruction. Throughout the nineteenth century until the First World War, libraries were created as institutions that were available not only to researchers, but gradually also to representatives of all social classes. It was a process that reflected, as in a mirror, the wider social changes taking place in Polish lands. Initially the founders of scientific libraries with a focus on the humanities came from the aristocracy and gentry, but from the mid-century, their ranks were joined by an increasing number of collectors from other professions, such as lawyers, politics, priests, teachers, and people of culture and art.

Keywords: public library, libraries, reading, education of Polish society, protection of cultural heritage

Celem niniejszego artykułu będzie syntetyczne ukazanie, jak od czasu utraty niepodległości w końcu XVIII wieku różne grupy społeczne, poczynając od arystokracji przez szlachtę, mieszczaństwo, duchowieństwo i uświadomione społecznie chłopstwo, dążyły do zachowywania i uczenia kultury polskiej poprzez tworzenie bibliotek. Te zaś były instytucjami służącymi do gromadzenia, ochrony i przechowywania księgozbiorów w języku polskim, ale także miały na celu edukację, wychowanie narodu polskiego oraz walkę 
z wynarodowieniem. Zbiory biblioteczne gromadzili zarówno Polacy zamieszkujący ziemie zagrabione przez zaborców, jak i ci, którzy znaleźli się na emigracji. Świadomość narodowa była tak silna, że dzięki takim inicjatywom społecznym na rzecz rozbudzania i zachowania świadomości narodowej w 1918 roku Polska mogła odzyskać niepodległość jako kraj, którego obywateli jednoczyły język i religia.

\section{Wprowadzenie}

Od średniowiecza tworzono i powiększano biblioteki: książęce, królewskie, katedralne, kolegiackie i zakonne, które służyły kształceniu przyszłych władców, urzędników państwowych i duchownych. Epoka oświecenia przyniosła zwiększone zapotrzebowanie na słowo drukowane $\mathrm{w}$ postaci książki. To spowodowało potrzebę tworzenia bibliotek, archiwów i muzeów. Wówczas w całej Europie zakładano towarzystwa naukowe, rozwijało się czasopiśmiennictwo i powstawały wydawnictwa encyklopedyczne. Już w XVII wieku na zachodzie Europy niektóre zbiory panujących i szlachty zostały otwarte dla uczonych, a później i dla szerszego grona użytkowników, wówczas odrodzeniowe sibi et amicis (sobie i przyjaciołom) przestało obowiązywać. W XVIII-XIX wieku w całej Europie było modne i rozpowszechnione kolekcjonerstwo, a w jego ramach bibliofilstwo.

Zjawisko to nie ominęło również ziem polskich, szczególnie rozwijało się wśród warstw ówczesnego oświeconego społeczeństwa: arystokracji, ziemiaństwa, szlachty, duchowieństwa oraz mieszczaństwa. Kolekcjonerstwo było wyrazem nie tylko osobistych zamiłowań, lecz także chęci dodania splendoru nazwisku czy siedzibie rodu. W końcu XVIII wieku, gdy zaborcy rozgrabili ziemie Rzeczypospolitej, jej obywatele, marzący o odzyskaniu niepodległości, zaczęli gromadzić książki, dokumenty, szeroko pojmowane pamiątki kultury narodowej z pobudek patriotycznych $-\mathrm{z}$ chęci ocalenia spuścizny minionych pokoleń (dorobku polskiej kultury), udostępnienia zbiorów badaczom, a także $\mathrm{z}$ palącej potrzeby edukacji społeczeństwa polskiego.

\section{Biblioteki arystokratyczne na chwałę rodu i pożytek narodu}

Najstarszą biblioteką publiczną w Polsce była biblioteka Załuskich, otwarta 8 sierpnia 1747 roku. Jej twórcami byli bracia Załuscy: Andrzej Stanisław ${ }^{1}$

\footnotetext{
${ }^{1}$ Andrzej Stanisław Załuski herbu Junosza (ur. 2 grudnia 1695 roku, zm. 16 grudnia 1758 roku) biskup płocki, łucki, chełmiński, krakowski, administrator apostolski diecezji pomezańskiej, w latach
} 
i Józef Andrzej². Zasadniczą część ich księgozbioru stanowiły dzieła historyczne, prawnicze, teologiczne i filozoficzne w różnych językach oraz czasopisma zagraniczne3. W 1870 roku instytucja otrzymała rangę biblioteki narodowej i nazwę Biblioteka Publiczna Rzeczypospolitej. Celem Załuskich, gdy powoływali bibliotekę, było wykreowanie w Warszawie centrum intelektualnego, którego osią miała być biblioteka publiczna pojęta szeroko jako warsztat pracy dla uczonych ${ }^{4}$.

Natomiast twórcą jednej z cenniejszych bibliotek, która stanowiła kompleks biblioteczno-drukarsko-wydawniczy, był hrabia Józef Maksymilian Ossoliński ${ }^{5}$, uczestnik powstania kościuszkowskiego. W 1817 roku powołał on we Lwowie Zakład Narodowy, który obejmował muzeum, bibliotekę i drukarnię. Ossolineum gromadziło skarby kultury polskiej oraz było kuźnią polskiej myśli naukowej i patriotycznej ${ }^{6}$.

W 1826 roku została założona przez Adama Tytusa Działyńskiego ${ }^{7}$ Biblioteka Kórnicka, w której zebrał on kilkadziesiąt tysięcy książek i rękopisów (poloników około 10 tysięcy). Na potrzeby biblioteki przeznaczył zamek w Kórniku i specjalnie przystosowany pawilon ogrodowy. W 1828 roku rozpoczął także działalność wydawniczą od edycji tekstów praw litewskich. Wszystkie jego dzieła były luksusowo i niezwykle starannie wydane ${ }^{8}$.

1735-1746 kanclerz wielki koronny; E. Giglilewicz, Zahuski Andrzej Stanistaw, w: Encyklopedia katolicka (dalej EK), t. 20, Lublin 2014, kol. 1216-1217.

${ }^{2}$ Józef Andrzej Załuski herbu Junosza (ur. 12 sierpnia 1702 roku, zm. 7 stycznia 1774 roku) biskup kijowski, kaznodzieja, polityk, mecenas nauki i kultury, bibliofil, polihistor, edytor, bibliograf, historyk, poeta, dramatopisarz, tłumacz, organizator życia literackiego; M. Batkiewicz, Załuski Józef Andrzej, w: EK, t. 20, Lublin 2014, kol. 1217-1218.

${ }^{3}$ Biblioteka Załuskich należała do najzasobniejszych w Europie, zawierała 180 tysięcy druków, 10 tysięcy manuskryptów, tysiące map, atlasów i sztychów. Księgozbiór zajmował 29 sal. Gabinet fizyczny, obserwatorium astronomiczne i muzeum osobliwości stanowily działy odrębne.

${ }^{4}$ Biblioteka Zahuskich, w: Encyklopedia wiedzy o książe, red. A. Birenmajer, B. Kocowski, J. Trzynadlowski, Wrocław-Warszawa-Kraków 1971, kol. 204-205; B. Szyndler, Biblioteka Załuskich, Kraków 1983; J. Kozłowski, Szkice o dziejach Biblioteki Zahuskich, Wrocław 1986; J. Płaza, B. Sajna, Pamiątki dziejów Biblioteki Zahuskich, Warszawa 1997; Corona urbis et orbis: Biblioteka Załuskich, oprac. H. Tchórzewska-Kabata, Warszawa 1998.

${ }^{5}$ Józef Maksymilian Ossoliński herbu Topór (ur. 1748 roku w Woli Mieleckiej, zm. 17 marca 1826 roku w Wiedniu) - powieściopisarz, poeta, badacz i historyk literatury, historyk, tłumacz, działacz kulturalny epoki oświecenia, założyciel Zakładu Narodowego im. Ossolińskich we Lwowie, któremu przekazał swój potężny księgozbiór; M. Cwenk, Ossoliński Józef Maksymilian, w: EK, t. 14, Lublin 2010, kol. 927-928.

${ }^{6}$ Zakład Narodowy im. Ossolińskich, w: Encyklopedia wiedzy o książce, kol. 2567-2573.

${ }^{7}$ Adam Tytus Działyński, hrabia (ur. 24 grudnia 1796 roku w Poznaniu, zm. 12 kwietnia 1861 roku tamże) - arystokrata, działacz polityczny, mecenas sztuki, wydawca źródeł historycznych; J. Bazydło, M. Wrzeszcz, Działyński Tytus Adam, w: EK, t. 4, Lublin 1983, kol. 462-463.

${ }^{8}$ Biblioteka Kórnicka PAN, w: Encyklopedia wiedzy o książce, kol. 191. 
Inna biblioteka wielkopolska - Biblioteka Raczyńskich powstała z fundacji hrabiego Edwarda Raczyńskiego ${ }^{9}$, wielkopolskiego magnata, działacza społecznego, mecenasa sztuki i nauki, autora i wydawcy. 5 maja 1829 roku w Poznaniu nastąpiło jej otwarcie w specjalnie do tego celu wzniesionym budynku. Pierwsza w Wielkopolsce książnica publiczna stała się regionalnym ośrodkiem kultury polskiej pod zaborem pruskim ${ }^{10}$. W opracowanym przez siebie statucie, określającym podstawy materialne placówki, organizację, zadania i zasady gromadzenia zbiorów, Raczyński pisał: „Niżej podpisany przejęty chęcią ułatwienia każdemu środków nabywania nauk i wiadomości zakłada w Poznaniu w miejscu swego urodzenia Bibliotekę publiczną, którą wraz $\mathrm{z}$ domem $\mathrm{w}$ tym celu (...) wystawionym, ze wszystkimi $\mathrm{w}$ nim znajdującymi się obecnie książkami, oraz funduszami na uposażenie przeznaczonymi, temuż miastu tytułem własności w wieczne nadaje posiadanie. (...) Przeznaczeniem Biblioteki Raczyńskich jest, aby w czytelni, która w tejże będzie urządzoną, każdy bez różnicy osób w dniach i godzinach oznaczonych miał prawo z niej korzystać"11.

W 1830 roku Bibliotece przyznano prawo do egzemplarza obowiązkowego wydawnictw ukazujących się na terenie Wielkiego Księstwa Poznańskiego. Księgozbiór powiększał się także dzięki nabywaniu przez Raczyńskiego i jego bibliotekarza Józefa Łukaszewicza ${ }^{12}$ cennych rękopisów, starych druków i obiektów kartograficznych. Istotne znaczenie miały ponadto dary. W 1835 roku żona Konstancja ofiarowała zakupioną od Juliana Ursyna Niemcewicza ${ }^{13}$ część jego prywatnej biblioteki, w której znajdowały się znakomite historyczne materiały źródłowe, cenne manuskrypty, starodruki i atlasy.

Obok wspomnianych wyżej bibliotek funkcjonowały jeszcze: Biblioteka Ordynacji Zamojskiej (Jan Zamoyski [1542-1605], prywatna biblioteka pałacowa w Zamościu, założona w latach siedemdziesiątych XVI

${ }^{9}$ Edward Raczyński herbu Raczyński, hrabia (ur. 2 kwietnia 1786 roku w Poznaniu, zm. 20 stycznia 1845 roku w Zaniemyślu) - ziemianin wielkopolski, działacz społeczny i polityczny, wydawca; B. Krasucka, Raczyński Edward, w: EK, t. 16, Lublin 2012, kol. 1054-1055.

${ }^{10}$ Biblioteki fundacyjne (B. Raczyńskich), w: Encyklopedia wiedzy o ksiażce, kol. 219-220.

11 Biblioteka Raczyńskich, Akt założenia i organizacji biblioteki publicznej $w$ Poznaniu (zachowany rękopiśmienny odpis aktu podpisany przez Edwarda Raczyńskiego, brak sygn.).

12 Józef Andrzej Łukaszewicz, ur. 30 listopada 1799 roku (29 listopada 1797 roku) w Krąplewie, zm. 13 lutego 1873 roku w Targoszycach) - historyk, publicysta, bibliotekarz i wydawca; O. Błaszczak, Łukaszewicz Józef Andrzej, w: EK, t. 11, Lublin 2006, kol. 626-627.

${ }^{13}$ Julian Ursyn Niemcewicz herbu Rawicz (ur. 16 lutego 1757 roku w Skokach na Polesiu, zm. 21 maja 1841 roku w Paryżu) - dramaturg, powieściopisarz, poeta, historyk, pamiętnikarz, publicysta, tłumacz, wolnomularz, zastępca wielkiego mówcy Wielkiej Loży Narodowej Wielkiego Wschodu Polskiego w 1781 roku; M. Cwenk, Niemcewicz Julian Ursyn, w: EK, t. 13, Lublin 2009, kol. 10771079 . 
wieku, po 1593 roku Biblioteka Akademii Zamojskiej) $)^{14}$; Biblioteka Czartoryskich $^{15}$ (Adam Kazimierz Czartoryski [1734-1823], założona w 1761 roku w Pałacu Błękitnym w Warszawie); Biblioteka Wilanowska (Ignacy Potocki [1750-1809], założona w latach siedemdziesiątych XVIII wieku w Warszawie i Kurowie ${ }^{16}$ ); Biblioteka Szczorszowska (Joachim Litawor Chreptowicz [1729-1812], założona w latach siedemdziesiątych XVIII wieku w Warszawie ${ }^{17}$ ); Biblioteka Dzikowska (Jan Feliks Tarnowski [1777-1842], założona ok. 1820 roku w Dzikowie) ${ }^{18}$; Biblioteka Dzieduszyckich (Józef Kalasanty Dzieduszycki [1776-1847], założona w 1815 roku w Poturzycy) ${ }^{19}$; Biblioteka Przeździeckich (Aleksander Przeździecki [1814-1871], założona w 1841 roku w Czarnym Ostrowie) ${ }^{20}$; Biblioteka Ordynacji Krasińskich (Wincenty Krasiński [1782-1858], założona w 1844 roku w Warszawie) ${ }^{21}$; Biblioteka hrabiego Wiktora Baworowskiego (Wiktor Baworowski [1826-

${ }^{14}$ Biblioteki fundacyjne (B. Ordynacji Zamojskiej), w: Encyklopedia wiedzy o książce, kol. 220; Biblioteka Ordynacji Zamojskiej: od Jana do Jana. Przewodnik po wystawie: Biblioteka Narodowa 17 maja - 17 lipca 2005 Muzeum Zamojskie 25 sierpnia - 2 października 2005 - The Zamoyski Library: from Jan to Jan. The National Library, Warsaw May 17 - July 17, 2005 The Zamość Museum August 25 - October 2, 2005, oprac. T. Makowski, Warszawa 2005; B. Horodyski, Biblioteka Ordynacji Zamojskiej w latach wojny, Warszawa 2005.

${ }^{15}$ K. Buczek, Bibljoteka Pulawska $w$ czasie walk powstania listopadowego, Kraków 1930; B. Smoleńska, Autografy ze zbiorów putawskich Izabeli Czartoryskiej w Bibliotece Narodowej, „Rocznik Biblioteki Narodowej” 1983, t. 15, s. 79-101.

${ }^{16}$ Biblioteki rodowe (B. Potockich), w: Encyklopedia wiedzy o książce, kol. 258-259; J. Rudnicka, Biblioteka Wilanowska - dwieście lat jej dziejów (1741-1932), Warszawa 1967; Dar dla Narodu. Skarby Biblioteki Wilanowskiej : wystawa ze zbiorów Biblioteki Narodowej pod honorowym patronatem prezydenta RP Aleksandra Kwaśniewskiego : Biblioteka Narodowa, Pałac Rzeczypospolitej, pl. Krasińskich 3/5, kwiecień - maj 2003, red. P. Buchwald-Pelcowa, Warszawa 2003.

${ }^{17}$ S. Ptašickì, Ŝrorsovskaâ biblìoteka grafa Litavora Hreptoviča, t. 1: Kratkiâ svěděniâ o sobranì rukopisej, Moskva 1899; Deržavna istorična biblioteka Ukraïni. Istoriâ, sučasnist', majbutnê. Materiali Mižnarodnoï naukovo-praktičnoï konferencï, priuročenoï do 7o-riččâ zasnuvannâ Deržavnoï istoričnoï biblioteki Ukraïni: 24-25 veresnâ 2009 r., red. A.V. Skorohvatova et al., Kiïv 2006.

${ }^{18}$ Biblioteki rodowe (B. Tarnowskich), w: Encyklopedia wiedzy o ksiażce, kol. 259-260; M. Marczak, Bibljoteka Tarnowskich w Dzikowie, Kraków 1921; A.F. Baran, Bibliotekarz z Dzikowa - dr Michat Marczak (1886-1945), Sandomierz 1996; A. Janas, Kolekcja dzikowska hr. Tarnowskich, Tarnobrzeg 2006.

${ }^{19}$ Biblioteki rodowe (B. Dzieduszyckich), w: Encyklopedia wiedzy o książce, kol. 257.

${ }^{20}$ Biblioteki fundacyjne (B. Ordynacji Przeździeckich), w: Encyklopedia wiedzy o ksiażce, kol. 219.

${ }^{21}$ Bibliotekifundacyjne (B. Ordynacji Krasińskich), w: Encyklopedia wiedzy o ksiażce, kol. 218219; I. Baranowski, Biblioteka Ordynacyi hr. Krasińskich w Warszawie, Warszawa 1911; Biblioteka Ordynacji Krasińskich 1844-1944. Przemówienia Edwarda Krasińskiego i Jana Muszkowskiego podczas uroczystego otwarcia Biblioteki i Muzeum Ordynacji Krasińskich, oprac. H. TchórzewskaKabata, Warszawa 2004; Droga do Okólnika 1844-1944. W 16o. rocznice powstania Biblioteki Ordynacji Krasińskich i w 6o. - spalenia zbiorów bibliotek warszawskich w gmachu BOK na Okólniku, oprac. i posł. H. Tchórzewska-Kabata, Warszawa 2005. 
1894], założona w 1857 roku w Myszkowicach) ${ }^{22}$; Biblioteka Suska (Aleksander Branicki [1821-1877], założona ok. 1866 roku w Suchej) ${ }^{23}$; Biblioteka Hutten-Czapskich w Krakowie założona przez Emeryka HuttenCzapskiego (1828-1896) ${ }^{24}$.

\section{Biblioteki polskie na obczyźnie dla emigrantów chcących zachować kulturę narodową}

$\mathrm{Na}$ emigracji również tworzono biblioteki zarówno naukowe, jak i oświatowe celem przeciwdziałania wynarodowieniu, ale i dla ułatwienia kształcenia dzieci emigrantów oraz szerzenia idei wyznawanych przez założycieli.

Biblioteki powstawały wszędzie tam, gdzie istniały większe skupiska emigrantów, poczynając od Francji, Anglii aż po obie Ameryki. Tworzono i organizowano je także na zesłaniu syberyjskim oraz w polsko-tureckim Adampolu. Praca tych bibliotek bywała prowadzona oryginalnie, a często również niestandardowo: chodziło o to, aby literatura i publikacje w języku polskim były dostępne dla jak największej rzeszy Polaków. Celem ich funkcjonowania było uczenie i przypominanie języka polskiego szczególnie emigrantom, którzy szybko asymilowali się ze środowiskiem oraz tym, dla których kontakt $\mathrm{z}$ językiem polskim był sposobem na przetrwanie katorgi i uchronienie polskości oraz wiary.

24 listopada 1838 roku w mieszkaniu Ludwika Platera powołano Publiczną Bibliotekę Polską $w$ Paryżu. Połączone zbiory towarzystw fundujących bibliotekę (Towarzystwo Pomocy Naukowej i Towarzystwo Literackie z Wydziałem Historycznym i Statystycznym) powierzone zostały opiece Rady Bibliotecznej, w której skład weszli: książę Adam Jerzy Czartoryski, dożywotni prezes oraz po dwóch przedstawicieli Towarzystw, zaś funkcję sekretarza objął Karol Sienkiewicz, jej inicjator i późniejszy pierwszy dyrektor ${ }^{25}$. Jej celem było zbieranie ocalałych od grabieży i zniszczeń książek,

${ }^{22}$ Biblioteki fundacyjne (B. Baworowskich), w: Encyklopedia wiedzy o książce, kol. 218; W. Kętrzyński, Biblioteka Wiktora hr. Baworowskiego we Lwowie, Lwów 1892; J. Szocki, Księgozbiór Wiktora Baworowskiego - lwowskiego kolekcjonera i fundatora biblioteki, w: Lwów - miasto, spoteczeństwo, kultura. Studia z dziejów Lwowa, t. 2, red. H.W. Żaliński, K. Karolczak, Kraków 1998, s. 448-455; tegoż, Wiktor Baworowski - lwowski kolekcjoner i fundator biblioteki, „Przegląd Wschodni” 1998, t. 5, z. 3(19), s. 544-550.

${ }^{23}$ A. Mężyński, Wielkoziemiańskie biblioteki publiczne w Polsce w latach 1772-1918, „Roczniki Biblioteczne" 2002, nr 44, s. 236-241.

${ }^{24}$ Biblioteki rodowe (B. Hutten-Czapskich), w: Encyklopedia wiedzy o książce, kol. 257; „Monumentis patriae..." Emerykowi Hutten-Czapskiemu $w$ 110. rocznice śmierci Muzeum Narodowe w Krakowie, red. J. Skorupska, tłum. M. Myszkiewicz, Kraków 2006.

${ }^{25}$ Biblioteka Polska w Paryżu, sygn. BPP 1534, Założenie Biblioteki Publicznej Polskiej w Paryżu, „Uchwała o Bibliotece Publicznej Polskiej”, s. 3-5; K. Seroka, Karol Sienkiewicz (1793-186o) pierwszy dyrektor Biblioteki Polskiej w Paryżu, w: Wzory i wzorce osobowe $w$ biografistyce 
archiwów i pamiątek narodowych. Biblioteka stała się ośrodkiem dokumentacyjnym pozostającym do dyspozycji Polaków oraz cudzoziemców. W 1845 roku posiadała 15 tysięcy tomów, a w 1848 roku było w niej już około 20 tysięcy książek ${ }^{26}$. Około 1830 roku w Baden pod Wiedniem także Gwalbert Pawlikowski założył bibliotekę ${ }^{27}$, jednak około 1835 roku jej księgozbiór został przewieziony do Medyki, a na przełomie $1848 / 1849$ do Lwowa ${ }^{28}$.

W 1848 roku Róża z Potockich Branicka zakupiła dla syna Ksawerego Branickiego ${ }^{29}$ zrujnowany zamek w Montrésor, gdy ten jako emigrant musiał opuścić dobra wołyńskie. Uczynił on $\mathrm{z}$ niego rodową siedzibę i zaczął gromadzić cenne pamiątki narodowe, dzieła sztuki, rękopisy, książki, trofea myśliwskie. Obok tych kolekcji zaczęła rozrastać się biblioteka, która liczyła około 10 tysięcy książek, między innymi były to publikacje polskie, francuskie oraz autografy wybitnych osobowości z obu krajów, listy, dokumenty z czasów powstania styczniowego, materiały dotyczące stosunków polsko-rosyjskich, korespondencję, archiwa majątkowe właścicieli zamku, atlasy i globusy ${ }^{30}$.

W 1870 roku hrabia Władysław Broël-Plater ${ }^{31}$ założył Muzeum Narodowe Polskie w Rapperswilu, którego nieodłączną częścią była biblioteka. $\mathrm{W}$ niedługim czasie zbiory biblioteczne $\mathrm{i}$ archiwalne przewyższyły zbiory muzealne, dlatego utworzono urząd bibliotekarza ${ }^{32}$. Zalążkiem Biblioteki Rapperswilskiej była kolekcja Leonarda Chodźki ${ }^{33}$ zakupiona w 1784 roku. Biblioteka Rapperswilska liczyła 91 tysięcy druków (książek, broszur, druków

pedagogicznej, red. R. Skrzyniarz, M. Gajderowicz, T. Wach, t. 3 serii „Biblioteka Katedry Biografistyki Pedagogicznej”, Lublin 2013, s. 164-165.

${ }^{26}$ Biblioteka Polska w Paryżu, w: Encyklopedia wiedzy o książce, kol. 196-198.

${ }^{27}$ Józef Gwalbert Pawlikowski (1793-1853) - używał tylko drugiego imienia; ziemianin, polityk galicyjski, botanik, mecenas sztuki, zbieracz i kolekcjoner książek, rękopisów, map, monet; M. Tyrowicz, Pawlikowski Józef Gwalbert, w: Polski słownik biograficzny (dalej: PSB), t. 25, Wrocław-Warszawa-Kraków 1980, s. 434-437.

${ }^{28}$ Biblioteki rodowe (B. Pawlikowskich), w: Encyklopedia wiedzy o ksiażce, kol. 258.

${ }^{29}$ Ksawery Branicki herbu Korczak (ok. 1814-1879) - szlachcic, finansista, działacz narodowy, kolekcjoner sztuki. Jedna z wybitniejszych postaci drugiego okresu Wielkiej Emigracji we Francji i najhojniejszych osób wspierających materialnie i organizacyjnie powstanie styczniowe w 1863 roku; A. Lewak, Branicki Ksawery, w: PSB, t. 2, Kraków 1936, s. 408-409.

${ }^{30}$ H. Łaskarzewska, M. Figiel, Polskie dziedzictwo kulturowe $w$ krajach Europy zachodniej, „Cenne, bezcenne, utracone” 2009, nr 2 (59), s. 24.

${ }^{31}$ Władysław Ewaryst Broël-Plater, ur. 7 listopada 1808 roku w Wilnie, zm. 22 kwietnia 1889 roku - poseł na Sejm powstańczy w czasie powstania listopadowego, dziennikarz i polityk emigracyjny, założyciel Muzeum Polskiego w Rapperswilu; S. Kieniewicz, Plater (Broël-Plater) Wtadystaw Ewaryst, w: PSB, t. 26, Wrocław-Warszawa-Kraków 1981, s. 686-691.

32 Pierwszym bibliotekarzem w Rapperswilu był Zygmunt Wasilewski (1892-1894), a po nim Stefan Żeromski (1892-1896).

${ }^{33}$ Leonard Chodźko herbu Kościesza (ur. 1800 roku w Oborku w powiecie oszmiańskim, zm. 12 marca 1871 roku w Poitiers) - polski historyk, geograf, kartograf, archiwista, wydawca polskich prac propagandowych i działacz emigracyjny; W. Borkowska, Chodźko Leonard, w: PSB, t. 3, Kraków 1937, s. 386-388. 
ulotnych i czasopism), 27 tysięcy rękopisów, dyplomów i autografów, 1,4 tysięcy map i atlasów, przeszło tysiąc zapisów nutowych i około 10 tysięcy fotografii ${ }^{34}$.

Biblioteka gromadziła zbiory emigracyjnych druków ulotnych, czasopisma okresu Wielkiej Emigracji, literatury politycznej wytworzonej przez skupiska polskie, kolekcję kościuszkowską oraz mickiewicziana. Zgodnie z testamentem hrabiego Platera po odzyskaniu przez Polskę niepodległości zbiory zostały przewiezione do kraju w 1927 roku. Niestety cenna kolekcja spłonęła w okresie II wojny światowej ${ }^{35}$.

Również w Stanach Zjednoczonych tworzono biblioteki służące kształceniu księży prowadzących działalność duszpasterską $\mathrm{w}$ polskich parafiach, ale także i Polonii, która chciała uczyć się języka polskiego i kultywować polskie tradycje na emigracji. W 1885 roku powstały archiwum, biblioteka i muzeum założone przez ks. Józefa Dąbrowskiego, które stanowią podwaliny obecnego Polonijnego Zakładu Naukowego Seminarium Polskiego w Orchard Lake w USA ${ }^{36}$.

\section{Książnice zakładane przez społeczności lokalne w celu propagowania czytelnictwa i oświaty}

Obok bibliotek wielkoziemiańskich w różnych regionach dawnej Rzeczypospolitej powstawały biblioteki, których inicjatorami byli przedstawiciele społeczności lokalnej lub osoby o wysokiej świadomości społeczno-narodowej, odczuwające konieczność propagowania czytelnictwa, edukacji i oświaty.

W XIX wieku, szczególnie poczynając od 1848 roku - Wiosny Ludów - nastąpiła aktywizacja społeczno-narodowa, a dzięki niej rozwój oświaty ludowej i masowego czytelnictwa. Tworzono na przykład biblioteki, księgozbiory i księgarnie na terenie Górnego Śląska, najstarszą z nich była biblioteka bytomska powstała w 1848 roku. Biblioteki obejmowały zbiory prywatne, szkolne, parafialne, ludowe oraz zbiory stowarzyszeń ${ }^{37}$. Nierzadko

\footnotetext{
34 Zbiory biblioteczne mieściły się w dwóch dużych salach zamkowych na drugim piętrze, zajmowały krużganek i 14 mniejszych pomieszczeń zamkowych.

${ }^{35}$ Biblioteka Rapperswilska, w: Encyklopedia wiedzy o książce, kol. 202-203.

${ }^{36}$ R. Nir, Stulecie Polskiego Seminarium w Orchard Lake w Stanach Zjednoczonych 1885-1985, Orchard Lake, Michigan 1987; tegoż, Archiwa, biblioteki i muzea polonijne $w$ Orchard Lake, „Archiwa, Biblioteki i Muzea Kościelne” 1993, nr 62, s. 111-146.

${ }^{37}$ A. Tokarska, Biblioteki polskie na Górnym Śląsku w XIX wieku, Katowice 1997.
} 
przy księgarniach powstawały wypożyczalnie książek ${ }^{38}$. Podobnie było na terenie Śląska Cieszyńskiego, co zostanie omówione poniżej39.

Księgozbiory mieszczańskie były gromadzone przede wszystkim przez inteligencję, patrycjat miejski, profesorów, lekarzy, prawników. Zbiory te miały charakter bibliofilski, zaś tematycznie były bardzo różnorodne. W okresie zaborów biblioteki mieszczańskie przeżywały zastój. W 1791 roku powstała Biblioteka Konfraterni Kupieckiej Warszawskiej, w 1805 roku Biblioteka Wileńskiego Towarzystwa Lekarskiego, w 1821 roku w Warszawie Biblioteka Towarzystwa Lekarskiego i Biblioteka Towarzystwa Resursy Kupieckiej ${ }^{40}$.

Były to przede wszystkim biblioteki specjalistyczne, w których gromadzono księgozbiory obejmujące jedną lub kilka pokrewnych dziedzin wiedzy. Natomiast na polskiej prowincji kolekcjonerzy, twórcy bibliotek, działacze wychowawczo-oświatowi stawali się jednoosobowymi instytucjami ogniskującymi życie kulturalne miejscowości i okolicy, w której żyli. Ich rozległe kontakty intelektualne ze światem zewnętrznym oddziaływały ożywczo na miejscowe społeczeństwo, dodatkowo inspirując inne społeczne poczynania.

Przykładami takich twórców mogą być Kajetan Morykoni ${ }^{41}$ i Anicety Renier $^{42}$. Pierwszy, pedagog i bibliotekarz, w latach 1811-1812 był inicjatorem i współzałożycielem Instytutu Bibliopolicznego w Lublinie, pierwszej biblioteki publicznej w tym mieście. Drugi był lekarzem, działaczem tajnej, niewielkiej biblioteczki założonej w 1840 roku w Wilnie. Warto także wspomnieć o bezpłatnej wypożyczalni stworzonej przez Władysława Tarczyńskiego na podstawie jego własnych zbiorów w Łowiczu.

W 1861 roku Wydział Czytelń Warszawskiego Towarzystwa Dobroczynności podjął się organizacji bezpłatnych czytelni dla niezamożnej ludności Warszawy. Dla bogatszych warstw mieszczańskich na terenie Warszawy działały także płatne wypożyczalnie istniejące przy księgarniach

\footnotetext{
${ }^{38}$ Tamże, s. 33 .

${ }^{39}$ Zbiór artykułów dotyczących księgozbiorów Śląska cieszyńskiego: Historyczne księgozbiory Cieszyna na tle śląskim. Rola kulturowa i przedmiot badań, red. R. Gładkiewicz, Cieszyn 1997.

${ }^{40}$ Biblioteki mieszczańskie, w: Encyklopedia wiedzy o książce, kol. 226.

${ }^{41}$ Kajetan Morykoni (ur. 2 września 1774 roku w Wełczu pod Buskiem, zm. 27 grudnia 1830 roku w Płocku) - pedagog, rektor Szkoły Wojewódzkiej Płockiej, założyciel Towarzystwa Naukowego Płockiego, wolnomularz; E. Kozłowski, Morykoni Kajetan, w: PSB, t. 22, Wrocław-WarszawaKraków 1977, s. 22-23.

${ }^{42}$ Anicety Renier (także Renjer, Regnier, Reniger, Renjé, lit. Anicetas Renjé, ur. ok. 1804 roku, zm. 24 grudnia 1877 roku w Wilnie) - polski lekarz zdrojowy i przyrodnik, uczestnik powstania listopadowego, działacz polityczny, bibliotekarz Wileńskiego Towarzystwa Lekarskiego. Urodził się prawdopodobnie w Lublinie. Syn Feliksa (nie Mikołaja, jak podają błędnie niektóre źródła); T. Ostrowska, Renier Anicety, w: PSB, t. 31, Wrocław-Warszawa-Kraków 1988, s. 109-110.
} 
lub samodzielnie, prowadzone przez osoby prywatne ${ }^{43}$. Organizację czytelni i bibliotek powszechnych podjęły się także towarzystwa oświaty ludowej: lwowskie (1864), poznańskie (1872) i krakowskie (1884) ${ }^{44}$. Zgonie z Ustawa o bezplatnej bibliotece ludowej z 1894 roku Mieczysław Brzeziński był zwolennikiem zakładania bibliotek na zebraniach gminnych, aby budować polskie struktury oświatowe ${ }^{45}$.

Terenem, na którym obserwujemy wiele inicjatyw zmierzających do zakładania bibliotek, był Śląsk Cieszyński, gdzie wśród kolekcjonerów i twórców bibliotek spotykamy nie tylko inteligencję, ale również chłopów. Podobne przykłady można wskazać również na Górnym Śląsku i w zachodnich powiatach wielkopolskich, na pograniczu babimojsko-międzyrzeckoskwierzyńskim, gdzie tradycje bibliotek ludowych sięgają trzeciej ćwierci XIX wieku We wspomnianych powiatach pod koniec XIX wieku (do 1905 roku) zorganizowano 36 bibliotek $^{46}$.

$\mathrm{Na}$ ziemiach polskich $\mathrm{w}$ okresie zaborów powstawały różnego rodzaju towarzystwa ${ }^{47}$ zajmujące się propagowaniem czytelnictwa wśród ludu wiejskiego, zakładaniem bezpłatnych wypożyczalni książek i pism, czytelni oraz popieraniem wydawnictw, szczególnie ludowych. Ich celem było umacnianie poczucia narodowego przez żywe słowo i książkę, a organizowana sieć czytelni miała za zadanie dotarcie do jak najszerszej grupy czytelników. Zakładano małe biblioteczki, które często były przewożone z miejsca na miejsce, aby czytelnik miał lepszy dostęp do książek. W 1890 roku Towarzystwo Oświaty Ludowej miało około 570 czytelni i wypożyczalni ${ }^{48}$, w ten sposób docierając do najbiedniejszych, których nie było stać na zakup nowych publikacji.

Jedną z cenniejszych bibliotek na Śląsku Cieszyńskim była biblioteka Czytelni Ludowej (obecnie wchodząca w skład Książnicy Cieszyńskiej), towarzystwa kulturalno-oświatowego, które od założenia w 1861 roku aż do połowy lat osiemdziesiątych XIX wieku stanowiło centrum polskiego życia narodowego w Cieszynie. Początki Biblioteki Czytelni Ludowej sięgają 1849 roku, kiedy to $\mathrm{w}$ ramach powstałego 15 listopada 1848 roku Towarzystwa

\footnotetext{
${ }^{43}$ M. Radwańska, Wypożyczalnie platne $w$ Warszawie w latach 1890-1906, „Studia o Książce” 1981, nr 11, s. 153-188.

${ }^{44}$ Biblioteki powszechne, w: Encyklopedia wiedzy o książce, kol. 249-250.

45 M. Jurczyszyn, Mieczystaw Brzeziński jako propagator czytelnictwa w Polsce, w: Wzory i wzorce osobowe $w$ biografistyce pedagogicznej, s. 81.

${ }^{46}$ G. Chmielewski, Polskie biblioteki ludowe na pograniczu zachodnim $w$ rejonie babimojskomiędzyrzecko-skwierzyńskim w latach 188o-1939, Zielona Góra 2002, s. 15 i nn.

47 Na przykład: Towarzystwo Czytelni Ludowych (Poznań 1889), Towarzystwo Czytelń m. Warszawy (1906), Towarzystwo Oświaty Ludowej (lwowskie 1867, krakowskie 1881).

${ }^{48}$ Towarzystwo Oświaty Ludowej, w: Encyklopedia wiedzy o książe, kol. 2365-2366.
} 
Cieszyńskiego dla Wydoskonalenia Się w Języku Polskim ${ }^{49}$, pierwszej oficjalnej organizacji polskiej w Cieszynie, utworzona została Biblioteka Polska dla Ludu Kraju Cieszyńskiego. Miała ona na celu gromadzenie i popularyzację literatury polskiej oraz oddziaływanie na szerokie kręgi społeczeństwa regionu. W jej skład, obok licznych darów, weszły zbiorki książek należące wcześniej do młodzieżowych kółek samokształceniowych, działających w gimnazjum ewangelickim. W 1854 roku Biblioteka Polska została rozwiązana, a jej zbiory skonfiskowano i włączono do biblioteki Leopolda Jana Szersznika ${ }^{50}$.

W 1863 roku Czytelnia Ludowa jako kontynuatorka Biblioteki Polskiej rewindykowała jej księgozbiór i stworzyła na jego podstawie własną bibliotekę, liczącą wówczas ponad 800 woluminów. Dzięki darowiznom polskich pisarzy, wydawców, księgarzy oraz bibliofilów księgozbiór Czytelni znacznie rozrósł się i w 1922 roku, gdy przekazano go Macierzy Szkolnej Księstwa Cieszyńskiego, obejmował już około 12 tysięcy woluminów. Wśród ofiarodawców, obok działaczy lokalnych, znajdowali się między innymi: Jan Milikowski ${ }^{51}$, Julia Goczałkowska $^{52}$, Klemens Mochnacki ${ }^{53}$, hrabia Mieczysław Dzieduszycki ${ }^{54}$,

49 „Celem Towarzystwa jest wydoskonalenie się jego członków w języku polskim poprzez pisma czasowe w języku polskim, słowniki i założenie małej biblioteki podrecznej w języku polskim, przez naukę języka polskiego"; M. Fazan, Polskie życie kulturalne na Ślasku Cieszyńskim $w$ latach 1842/48-1920, Wrocław-Warszawa [b.r.w.], s. 55; Z. Jasiński, Biblioteki polskie na ziemiach czeskich, w: Leksykon Polaków w Republice Czeskiej i Republice Stowackiej, t. 2, Opole 2013, s. 23.

${ }^{50}$ Jan Szersznik - inne formy jego nazwiska: Scherschnik, Šeršnik, (ur. 3 marca 1747 roku w Cieszynie, zm. 21 stycznia 1814 roku tamże) - ksiądz katolicki, jezuita, historyk, pedagog, slawista, bibliofil, fundator biblioteki i pionier muzealnictwa. O Szerszniku i Książnicy Cieszyńskiej: K. Szelong, Proces windykacji i opracowania bibliotecznych zbiorów ks. Leopolda Jana Szersznika. Zarys historï, „Roczniki Biblioteczne” 2000, nr 44, s. 87-134.

${ }^{51}$ Jan Milikowski (1781-1866), polski księgarz; J. Golec, S. Bojda, Stownik biograficzny ziemi cieszyńskiej, t. 2, Cieszyn 1995, s. 146.

52 Julia Goczałkowska (1809-1888) była redaktorką kobiecych pism „Bławatek” i „Wianki” oraz organizatorką zakładów wychowawczo-naukowych dla dziewcząt w Bochni, Tarnowie i Lwowie. Pochodziła z Laskowej, wraz z mężem, Wojciechem Goczałkowskim, byłym powstańcem 1831 roku, dzierżawiła przez kilkanaście lat majątki cerekwickie w Ostrowie Szlacheckim i Zatoce; A. Fischer, Płyń piękna kolędo..., „Zwiastun Maryi. Miesięcznik bazyliki mniejszej św. Mikołaja w Bochni”, 12.12.2010, nr 12 (171), s. 6.

${ }^{53}$ Klemens Mochnacki (1811 - ok. 1883) - rewolucyjny demokrata, spiskowiec; daleki krewny Maurycego Mochnackiego; K. Mochnacki, Pamiętnik spiskowca i nauczyciela, „Twórczość” 1950 z. 1.

${ }^{54}$ Mieczysław Antoni Dzieduszycki (1823-1872) działacz społeczny i oświatowy, popierający narodowe odrodzenie na Śląsku, publicysta, poeta; M. Tyrowicz, Mieczysław Antoni Dzieduszycki, w: PSB, t. 6 (1948) s. 116-117. 
Józef Ignacy Kraszewski ${ }^{55}$, ksiądz Karol Teliga ${ }^{56}$, spadkobiercy Ignacego Bagieńskiego $^{57}$, Towarzystwo Kształcącej się Młodzieży Polskiej w Monachium; systematycznie przesyłał swoje wydawnictwa Zakład Narodowy im. Ossolińskich we Lwowie ${ }^{58}$. Był to księgozbiór przydatny do upowszechniania kultury polskiej, szczególnie w kręgach o wyższej świadomości kulturowej. Zainteresować mógł on inteligencję, ewentualnie bogate chłopstwo, które lepiej było przygotowane do wejścia w kręgi literatury polskiej ${ }^{59}$.

Warto tu wspomnieć o jednym z darczyńców, którym był trzykrotny rektor Uniwersytetu Jagiellońskiego, dziekan Kapituły Krakowskiej, ks. Karol Teliga. Ofiarował on w 1876 roku Czytelni Ludowej 1027 dzieł w 1884 woluminach ze wszystkich działów literatury, przeważnie o treści religijnej, $\mathrm{w}$ tym wiele starych i cennych druków oraz rękopisów. W spisie przekazującym księgozbiór Teligi zapisano: „ks. Karol Teliga (...) kierowany chęcią przyczynienia się do rozkrzewiania oświaty między ludnością polską na Śląsku austriackim, ofiarował Czytelni Ludowej w Cieszynie bibliotekę swoją" ${ }^{0}$. Teliga był synem chłopskim o wysokiej świadomości narodowej, wiedział, że przekazanie księgozbioru do Cieszyna posłuży wzbogaceniu biblioteki, ale przede wszystkim wpłynie na wzrost czytelnictwa i świadomości narodowej tamtejszej społeczności. Dzięki polskiej książce jego mieszkańcy będą mieli kontakt z polską kulturą, zaś $\mathrm{w}$ wielu $\mathrm{z}$ nich wykształci to trwały nawyk czytania, który przekażą swojemu potomstwu. Teliga miał świadomość, że przekazanie zbiorów bibliotece pogranicza polskiego jest bardziej konieczne niż wsparcie mieszkańców ziem polskich, żyjących w jednorodnej społeczności.

Być może systematyczne propagowanie czytelnictwa wśród społeczności Śląska Cieszyńskiego było efektem poziomu kulturalnego chłopów cieszyńskich końca XIX wieku, którym zachwycał się w swoim

55 Józef Ignacy Kraszewski (1812-1887) - pisarz, publicysta, wydawca, historyk, działacz społeczny i polityczny; A. Bednarek, Kraszewski Józef Ignacy, w: EK, t. 9, Lublin 2002, kol. 12191223.

${ }^{56}$ Karol Teliga (ur. 30 października 1808 roku w Bielinach, zm. 9 marca 1884 roku w Krakowie) - duchowny katolicki, teolog, w 1862 roku administrator diecezji krakowskiej, profesor i trzykrotny rektor Uniwersytetu Jagiellońskiego; R. Skrzyniarz, Teliga Karol, EK, t. 19, Lublin 2013, kol. 602.

${ }^{57}$ Ignacy Bagiński, ur. 1760, data śmierci nieznana.

${ }^{58}$ F. Zahradnik, Czytelnia Ludowa w Cieszynie, ,Zaranie Śląskie” 1963, z. 2, s. 157.

${ }^{59}$ M. Fazan, Polskie życie kulturalne na Śląsku Cieszyńskim, s. 62.

${ }^{60}$ Archiwum Narodowe w Krakowie, sygn. IT 223, Spis dziet Czytelni Ludowej w Cieszynie przez ks. Karola Telige ofiarowanych, s. 3 . 
pamiętniku Grzegorz Smólski ${ }^{61}$ : „Wszędzie, u każdego zamożnego chłopa (...) nie brak i szafek z książkami treści religijnej i światowej, między tymi ostatnimi często pisma Mickiewicza i innych poetów, doborowe powieści polskich pisarzy jakoż i książki odnoszące się do naszych dziejów"62. To by świadczyło o tym, że czytelnictwo wśród bogatszych i bardziej świadomych chłopów rozwijało się mimo niekorzystnych okoliczności zewnętrznych.

\section{Konkluzje}

Reasumując, można stwierdzić, iż od końca XVIII stulecia aż do odzyskania przez Polskę niepodległości w 1918 roku zarówno biblioteki tworzone na ziemiach polskich $\mathrm{w}$ trzech zaborach, jak i te, które powstawały wśród emigrantów czy zesłańców miały na celu przede wszystkim naukę języka polskiego, edukowanie i wychowanie młodego pokolenia Polaków do niepodległości Rzeczypospolitej. Były także kuźnią postaw patriotycznych i religijnych wśród narodu polskiego. Zbierana w nich literatura miała na celu nie tylko przypominanie o niegdysiejszej wielkości Rzeczypospolitej, ale też wskazywanie dróg, jakimi należy kroczyć, aby nie zagubić tożsamości narodowej, wielowiekowej tradycji i wiary chrześcijańskiej przodków. Bez względu na to, gdzie powstawały, ich podstawową rolą było edukowanie Polaków.

Biblioteki służyły także ratowaniu polskiej literatury, pism, dokumentów, listów, pamiętników oraz pogłębianiu znajomości języka polskiego wśród młodych ludzi najbardziej narażonych na wynarodowienie, uleganie polityce szkolnej zaborców, podporząakowanie się nakazom władz. Biblioteki miały na celu zabezpieczenie księgozbiorów przed rozproszeniem, a przede wszystkim udostępnienie go szerszemu gronu czytelników. Po utracie niepodległości tworzenie takich „przyczółków kultury i języka polskiego” stało się koniecznością w celu zachowania polskości, zwłaszcza na kresach kultury polskiej, ale także służyło walce $\mathrm{z}$ wynaradawianiem społeczeństwa polskiego, szczególnie na terenach wiejskich, gdzie pod koniec XIX wieku we wsiach Królestwa Polskiego tylko 30\% osób umiało czytać i pisać, a wieś oczekiwała na polskie czasopisma i książki.

Jest to krótka refleksja nad rolą bibliotek w utrwaleniu języka i polskości w różnych warstwach społecznych. Warto by było podjąć głębsze badania nad rolą poszczególnych bibliotek w propagowaniu polskości. W jaki sposób ich założyciele i działacze społeczni chcieli wykorzystać zgromadzone

\footnotetext{
${ }^{61}$ Grzegorz Smólski, krypt., i pseud.: G.S., Grzela z Waszkowic, Wojciech Gorazda (1844-1911) dziennikarz, publicysta, krajoznawca i etnograf; W. Bieńkowski, Smólski Grzegorz, w: PSB, t. 39, Warszawa-Kraków 1999, s. 362-365.

${ }^{62}$ G. Smólski, $Z$ pamiętnika dziennikarza: Silesiana, Kraków 1896, s. 15; K. BednarskaRuszajowa, Biblioteki i ksiażki w pamiętnikach polskich XVIII-XX wieku, Kraków 2003, s. 71.
} 
zbiory do krzewienia polskości w narodzie? Jakie formy przybierały ich działania skierowane do przedstawicieli różnych warstw społecznych?

Wykorzystując metody badawcze stosowane w naukach humanistycznych i społecznych, odczytując ponownie znane już źródła i odkrywając nowe, można zastanowić się nad znaczeniem bibliotek nie tylko dla zachowania kultury narodowej, uczenia tradycji i języka wśród warstw niepotrafiących czytać i pisać, ale także nad rolą w kształtowaniu patriotyzmu lokalnego i budowaniem więzi z małą ojczyzną. Należy pamiętać, że wiele z tych bibliotek, o których wspominam, zostało zdziesiątkowanych przez wojny, ale może $\mathrm{w}$ niektórych przypadkach uda się ustalić ich rolę w alfabetyzacji i wychowaniu patriotycznym społeczeństwa polskiego okresu niewoli narodowej.

Streszczenie: W XVIII-XIX wieku w całej Europie rozpowszechniło się kolekcjonerstwo, a w jego ramach bibliofilstwo. Pod koniec XVIII wieku, gdy obywatele rozgrabionej przez zaborców Rzeczypospolitej zaczęli dążyć do odzyskania niepodległości - chęć ocalenia dorobku kultury polskiej była celem działalności wielu patriotów. Tworzyli oni kolekcje, które stawały się skarbnicami kultury polskiej, służyły ratowaniu przed rozproszeniem lub zniszczeniem oraz opracowaniu polskiej literatury, dokumentów, listów, pamiętników, dorobku naukowego, a także dawały początek inicjatywom zmierzającym do edukacji całego narodu polskiego i walki z wynarodowieniem. W ciągu całego XIX stulecia aż do I wojny światowej tworzenie bibliotek jako instytucji dostępnych nie tylko dla badaczy, ale i przedstawicieli wszystkich stanów było procesem, w którym jak w zwierciadle odbijają się przemiany społeczne, zachodzące na ziemiach polskich: początkowo założycielami bibliotek naukowych o profilu głównie humanistycznym były arystokracja i ziemiaństwo, zaś od połowy stulecia coraz częściej przedstawiciele wolnych zawodów: adwokaci, politycy, księża, nauczyciele, ludzie kultury i sztuki.

Słowa kluczowe: biblioteki publiczne, księgozbiory, czytelnictwo, edukacja społeczeństwa polskiego, zabezpieczenie dorobku kulturowego 